4. Latron F, Pazmany L, Morrison J et al. (1992) A critical role for conserved residues in the cleft of HLA-A.2 in presentation of a nonapeptide to T cells. Science 257: 964-967

5. Silver ML, Guo H-C, Strominger JL, Wiley DC (1992) Atomic structure of a human MHC molecule presenting an influenza virus peptide. Nature $360: 367-369$

6. Chicz RM, Urban RG, Lane WS et al. (1992) Predominant naturally processed peptides bound to DR-1 are derived from an MHC-related molecule and heterogeneous in size. Nature 358: 764-768

7. Rudensky AY, Preston-Hurlburt P, Al-Ramadi BK, Rothbard J, Janeway CA Jr (1992) Truncation variants of peptides isolated from MHC class II molecules suggest sequence motifs. Nature 359: 429-431

8. Brown JH, Jardetzky T, Saper MA, Samraoui B, Bjorkman PJ, Wiley DC (1988) A hypothetical model of the foreign antigen binding site of class 1 histocompatibility molecules. Nature 332: $845-850$

9. Ohashi PS, Oehen S, Buerki Ket al. (1991) Ablation of tolerance and induction of diabetes by virus infection in viral antigen transgenic mice. Cell 65: 305-317

\section{Response from the author}

Dear Sir,

In reply to Dr. Papadopoulos, I would agree with him that we can only make guesses about the manner in which class II HLA antigens and the peptides they bind interact. As he points out, the evidence favours a model in which class II antigens may bind much longer peptides than do class I antigens. The anchoring is presumed to be by aminoacid residues that hydrogen bond to various parts of the HLA class II structure. In our model we chose charged residues belonging to the third hypervariable region of DR or DQ- $\beta$ molecules as likely discriminators which might either assist or repel binding of a peptide such as $\mathrm{ABBOS}$ by hydrogen bonding or by charge repulsion or attraction. The actual binding may or may not be mediated through these "discriminator". residues, but in our hypothesis they strongly influence the binding function.

Teleologically such discriminators must exist otherwise specificity and selection of peptide binding by class II alleles would not be
10. Andersen LC, Beatly JJ, Nettles JW, Nepom GJ, Nepom BS (1991) Allelic polymorphism in transcriptional regulatory regions of HLA-DQ $\beta$ genes. J Exp Med 170: 470-481

Dr. G.K. Papadopoulos

Laboratory of Biological Chemistry

University of Ioannina Medical School

GR-451 10 Ioannina

Greece

Note added in proof. The three-dimensional structure of the HLADR1 molecule has recently been reported (Brown et al. (1993) Nature 364: $33-39$ ) and shows many similarities to published MHC class I structures. The three principles of peptide binding outlined above seem to hold. Likewise, the ends of the two $\alpha$-helices are closer to the $\beta$-sheet floor, permitting longer peptides to bind and allowing for the formation of a salt bridge between $\alpha 76 \mathrm{Arg}$ and $\beta 57$ Asp, directly under the bound peptide.

a reality. As Dr. Papadopoulos remarks, "the alignment of the ABBOS peptide in the antigen binding groove must be performed again" when we know more about anchor specificities of class II molecules.

We all look forward to the day when this is possible.

Yours sincerely,

B.H. Robinson

Dr. B. H. Robinson

Division of Genetic Metabolic Diseases

The Hospital for Sick Children

555 University Avenue

Toronto, Ontario

Canada M5G IX8

Randle from $1968[5,6]$ to resolve this issue by direct analysis of glucose phosphorylation in homogenates of isolated islets, seemed to show the presence of low $\mathrm{K}_{\mathrm{m}}$ hexokinase activity but a lack of glucokinase. Our first publication on this topic appeared in May 1968 [3], and demonstrated that islet tissue contained both (a) low $\mathrm{K}_{\mathrm{m}}$ hexokinase(s) and a high $\mathrm{K}_{\mathrm{m}}$ hexokinase (which we classified as glucokinase). This paper also reported the presence of glucose 6-phosphatase, confirming the data of Taljedal [7]. Additionally it provided the first clear direct evidence that intra- and extracellular glucose of islet cells equalized within minutes of an i.v. glucose load thus resembling liver cells. Glucose loading caused elevations of islet glucose 6-phosphate and fructose 1,6-bisphosphate presumably a manifestation of activation of glycolysis.

On the basis of these data we were able to formulate a plausible concept of beta cell glucose metabolism involving glucokinase as a key element [3]:

"The scheme of carbohydrate metabolism of the islets of Langerhans, emerging from these and other studies, has great similarities to the situation found in liver. The membrane properties of $\beta$-cells, the probable presence of two glucose phosphorylating enzymes with high and low affinity for the substrate, and the ability to liberate free glucose from glucose 6-phosphate constitute ideal conditions for rapid adjustments of glycolysis to blood glucose levels." 
This publication and two related papers $[8,9]$ resulted from the systematic application of the powerful technology of quantitative histochemistry developed by O. H. Lowry and his associates and was made feasible by a novel oil well method and enzymatic cycling to determine enzymes and metabolites of glucose metabolism in microscopic structures [10] as, for instance, the glucose sensitive insulin secreting pancreatic islets.

Following our 1968 report Ashcroft and Randle evidently improved their methodology to measure up to the difficult task at hand and in 1970 [11] they confirmed the presence of glucokinase in islets correcting their earlier erroneous findings $[5,6]$.

We feel that it is not presumptious to claim, that our laboratory deserves the credit for discovering glucokinase in islet tissue and that it has played a leading role in developing the glucokinase glucose sensor paradigm. It seems fitting to acknowledge here that during its early stages our research was strongly influenced by the work of Cahill [12], Weinhouse [13] and Sols [14] on glucose metabolism in liver, by the physiological studies of Grodsky with the isolated perfused rat pancreas [15], and by the methodological contributions of the Lowry School [10] which made measurements in microscopic structures possible. More recently the discoveries of molecular biologists $[16,17]$ and human geneticists [18], have added an exciting, entirely new dimension to this field of diabetes research. We have used several opportunities to review and discuss our contributions and those of others in the field [19-22].

Respectfully,

F.M.Matschinsky

\section{References}

1. Randle PJ (1993) Glucokinase and candidate genes for type 2 (non insulin-dependent) diabetes mellitus. Diabetologia 36:269275

2. Coore HG, Randle JJ (1964) Regulation of insulin secretion studied with pieces of rabbit pancreas incubated in vitro. Biochem $\mathrm{J}$ 93: 66-78

3. Matschinsky FM, Ellerman JE (1968) Metabolism of glucose in the Islets of Langerhans. J Biol Chem 243: 2730-2736

4. Grodsky GM, Batts AA, Bennett LL, Vcella C, McWilliams NB, Smith DF (1963) Effects of carbohydrates on secretion of insulin from isolated rat pancreas. Am J Physiol 205: 638-644

5. Ashcroft SJH, Randle PJ (1968) Glucose phosphorylation in mouse pancreatic islets. Biochem J 107: 599-600

6. Ashcroft SJH, Randle PJ (1968) Glucose metabolism and insulin release by pancreatic islets. Lancet I: $278-279$

\section{Response from the author}

Dear Sir,

Thank you for the opportunity to respond to Dr. Matschinsky's letter in relation to my review article entitled "Glucokinase and candidate genes for Type 2 (non-insulin-dependent) diabetes mellitus" [1].

The review did not claim that Coore and Randle (1964) [2] discovered glucokinase (GK) in pancreatic islets. What it did claim, and correctly, was that Coore and I [2-4] were the first to suggest that GK is the glucoreceptor for glucose induced insulin release and to provide evidence for it. Matschinsky and Ellerman (1968) [5] were the first to provide direct evidence for intracellular glucose and GK in pancreatic islets as my article also makes clear. Shortage of space prevented me from mentioning that their studies were on islets of obese hyperglycaemic mice - not normal mice; and that the relevance of their findings to normal islets was not established, nor indeed alluded to, by them. Ashcroft and Randle $(1969,1970)[6,7]$
7. Täljedal IB (1967) Some aspects of apparent glucose 6-phosphatase activity in the pancreatic islets of mammals. Biochem Biophys Acta 146: 292-295

8. Matschinsky FM, Kauffman FC, Ellerman JE (1968) Effect of hyperglycemia on the hexose monophosphate shunt of islets of Langerhans. Diabetes 17: 475-480

9. Matschinsky FM, Rutherford CR, Ellerman JE (1968) Accumulation of citrate in pancreatic islets of obese hyperglycemic mice. Biochem Biophys Res Commun 33: 855-862

10. Matschinsky FM, Passonneau JV, Lowry OH (1968) Quantitative histochemical analysis of glycolytic intermediates and cofactors with an oil well technique. J Histochem Cytochem 16:29-39

11. Ashcroft SJH, Randle PJ (1970) Enzymes of glucose metabolism in normal mouse pancreatic islets. Biochem J 119: 5-15

12. Cahill GF, Ashmore J, Earle AS, Zottu S (1958) Glucose penetration into liver. Am J Physiol 192: 491-496

13. Di Pietro DL, Sharma C, Weinhouse S (1962) Studies on glucose phosphorylation in rat liver. Biochemistry 1: 455-462

14. Vinuela E, Salas M, Sols A (1963) Glucokinase and hexokinase in relation to glycogen synthesis. J Biol Chem 238: PC1175PC1177

15. Grodsky GM, Bennett LL, Smith DF, Schmid FG (1967) Effect of pulse administration of glucose or glucagon on insulin secretion in vitro. Metabolism 16:222-233

16. Magnuson M (1990) Glucokinase gene structure: functional implications of molecular genetic studies. Diabetes 39: 523-527

17. Permutt MA, Chiu KC, Tanizawa Y (1992) Glucokinase and NIDDM. A candidate gene that paid off. Diabetes 41:1367-1372

18. Froguel Ph, Zouali H, Vionnet N et al. (1993) Familial byperglycemia due to mutations in glucokinase. Definition of a subtype of diabetes mellitus. N Engl J Med 328: 697-702

19. Meglasson MD, Matschinsky FM (1984) New perspectives on pancreatic islet glucokinase. Am J Physiol 246: E1 -E13

20. Meglasson MD, Matschinsky FM (1986) Pancreatic islet glucose metabolism and regulation of insulin secretion. Diabetes Metab Rev 3: 163-214

21. Matschinsky FM (1990) Glucokinase as glucose sensor and metabolic signal generator in pancreatic beta-cells and hepatocytes. Diabetes 39: 647-652

22. Matschinsky FM, Liang Y, Kesavan P et al. (1993) Glucokinase as pancreatic $\beta$-cell glucose sensor and diabetes gene. J Clin Invest: in press

Professor F. M. Matschinsky

Diabetes Research Center

501 Stemmler Hall

36th and Hamilton Walk

Philadelphia, PA 19104-6015

USA

were therefore the first to address the more difficult and important problem viz. to show the presence of $\mathrm{GK}$ in normal mouse islets. This was difficult (not erroneous as suggested by Dr. Matschinsky) because the ratio of GK to hexokinase was less favourable. Success was eventually achieved by specifically inhibiting hexokinase with excess glucose 6-phosphate which also had the advantage of nullifying possible interference by glucose 6-phosphatase (our assay method , followed the conversion of $\left[1-{ }^{14} \mathrm{C}\right]$ glucose to $\left[1-{ }^{14} \mathrm{C}\right]$ glucose 6 -phosphate which was diluted out by the unlabelled glucose 6-phosphate). This was important. The discovery by Ashcroft and Randle (1968, 1970) $[7,8]$ that islet glucose 6-phosphatase is inhibited by glucose (competitive $\mathrm{K}_{\mathrm{i}} 8.9 \mathrm{mmol} / \mathrm{l}$ [7]), meant that a mixture of soluble and particulate hexokinase plus particulate glucose 6-phosphatase could, in theory, simulate the kinetics given by a mixture of hexokinase and GK. It is possible therefore that the conclusions of Matschinsky and Ellerman were erroneous; their non-radioactive assay precluded inhibition of hexokinase with glucose 6-phosphate or dilution out of the effects of glucose 6-phosphatase. To the best of my 
knowledge this point has not been referred to by Dr. Matschinsky and I have not published it before.

In 1971-1973 Dr. Matschinsky and his colleagues published a series of papers purporting to show that stimulation of insulin release by sugars is not dependent on their metabolism and therefore that GK could not be the glucoreceptor i.e. they disowned the GK paradigm which he claims to have discovered. The following quotations are illustrative: in the summary of Landgraf et al. (1971) [9] "it is postulated that a glucoreceptor of broad specificity is involved in the mechanism of insulin release and that metabolism of glucose is not an essential part of the releasing action of this sugar"; in the summary of Matschinsky et al. (1971) [10] "These results and reports by other investigators suggest that glucose itself rather than its metabolites stimulate insulin secretion"; and in Matschinsky and Ellerman (1973) [11] "our current working hypothesis is that glucose acts by stimulating glucoreceptor molecules located in the $\beta$-cell membrane". Dr. Matschinsky's eventual reconversion to the GK/glucoreceptor hypothesis was effected from 1973 onwards mainly as a result of others failing to confirm his evidence purporting to show that metabolism of sugars and their insulin secretory effects in islets can be dissociated. I have already summarised in the review Dr. Ashcroft's later work on $\mathrm{N}$-acetylglucosamine which in my opinion clinched the $\mathrm{GK} /$ glucoreceptor hypothesis; I have acknowledged the importance of Dr. Matschinsky's later work in the 1980s; and I have reviewed the important molecular biological studies including the most important discovery of GK mutations.

Those who reviewed my article before acceptance for publication were kind enough to say that it was balanced and certainly the intent was to give a brief and accurate historical statement. Dr. Matschinsky has yet to tell us why he consistently failed to cite the paper of Coore and Randle (1964) until a publication in 1971 [10] in which he switched his allegiance to the direct glucose receptor hypothesis. The work which Dr. Coore did as a graduate student was pioneering in so many ways; and in addition to the preparation which he developed, and the discoveries mentioned here and in the review, he also discovered the inhibition of insulin secretion by adrenaline [2, 4]. Dr. Coore is currently Professor of Biochemistry in the University of the West Indies in Trinidad.

Yours sincerely,

P.J. Randle

\section{References}

1. Randle PJ (1993) Glucokinase and candidate genes for type 2 (non-insulin-dependent) diabetes mellitus. Diabetologia 36: 269-275

2. Coore HG, Randle PJ (1964) Regulation of insulin secretion studied with pieces of rabbit pancreas incubated in vitro. Biochem $\mathbf{J}$ 93: $66-78$

3. Randle PJ (1964) Rate of release of insulin in vitro. Ciba Foundation Colloquia Endocrinol 15: 107-113

4. Randle PJ (1964) Possible indirect effects of adrenaline on glycogen metabolism. In: Whelan WJ, Cameron MP (eds) Ciba Foundation Symposium on control of glycogen metabolism. Churchill, London, pp 294-297

5. Matschinsky FM, Ellerman JE (1968) Metabolism of glucose in the islets of Langerhans. J Biol Chem 243: 2730-2736

6. Ashcroft SJH, Randle PJ (1969) Carbohydrate metabolism and the release of insulin. Biochem J 112: $1 P$

7. Ashcroft SJH, Randle PJ (1970) Enzymes of mouse pancreatic islets. Biochem J 119: 5-15

8. Ashcroft SJH, Randle PJ (1968) Glucose 6-phosphatase activity of mouse pancreatic islets. Nature (Lond) 219:857-858

9. Landgraf R, Kotler-Brajtburg J, Matschinsky FM (1971) Kinetics of insulin release from the perfused rat pancreas caused by glucose, glucosamine and galactose. Proc Natl Acad Sci USA 68: $536-540$

10. Matschinsky FM, Ellerman JE, Krzanowski J, Kotler-Brajtburg J, Landgraf R, Feitel R (1971) The dual function of glucose in islets of Langerhans. J Biol Chem 246: 1007-1011

11. Matschinsky FM, Ellerman JE (1973) Dissociation of the insulin releasing and the metabolic functions of hexoses in islets of Langerhans. Biochem Biophys Res Commun 50: 193-199

Professor P.J. Randle

Nuffield Department of Clinical Biochemistry

John Radcliffe Hospital

Headington

Oxford OX3 9DU

UK 